\title{
Should the wildlife media pay for conservation? A response to Wunder \& Sheil
}

\author{
PAUL JEPSON and STEVE JENNINGS
}

$I^{n}$ our recent Science Policy Forum we asked whether media corporations producing and commissioning nature-based programming should adopt payment for ecosystem services (PES) principles (Jepson et al., 2011). Our purpose was to prompt discussion on the boundaries of PES logics: where do they start to break down? In addition, we suggested that exploring questions of whether and how the wildlife media should pay for ecosystem services would prompt a valuable review of the relationship between wildlife film-making and conservation.

We therefore welcome Wunder \& Sheil's response to our article and this opportunity to discuss the three points they make, namely: (1) that the PES-style scheme we outlined is a tax, (2) that the wildlife media contribute to conservation in varied and significant ways, and (3) that mechanisms designed to generate cash from 'structurally important conservation pillars' are short-sighted.

Wunder \& Sheil (2013) assert that PES systems are voluntary resource transfers from service users to service providers to conditionally maintain or improve service delivery. This represents an environmental economics perspective that aligns PES with exchange-value theory (Gómez-Baggethun et al., 2010). Our alignment is more with ecological economics and the view that the characteristics of the ecosystem services should influence the institutional design of PES mechanisms (Farley \& Costanza, 2010). Moreover, as Westman (1977) noted, valuing ecosystem services is a 'quintessential task of politics'. As a result the concept is continually being redefined, expanded and aligned. We prefer to think of PES as an umbrella term signifying ongoing efforts to devise mechanisms whereby users of ecosystem services contribute towards the cost of their conservation and restoration.

This said, our proposed monetization, a common asset trust design (Jepson et al., 2011), substantially meets Wunder \& Sheil's definition of a PES system. It is clearly voluntary: media companies would choose whether or not to seek certification. It involves a resource transfer from service users to providers albeit indirectly and via a trust. In addition, the proposed certification requirement for participating broadcasters to contribute location data on

PAUl Jepson (Corresponding author) School of Geography and the Environment, University of Oxford, South Parks Road, Oxford, OX1 3QY, UK. E-mail paul.jepson@ouce.ox.ac.uk

Steve Jennings Oxfam-UK, Cowley, Oxford, UK

First published online 28 August 2013. the wildlife images they broadcast in combination with the potential stability of payments under a trust mechanism was intended to create opportunities for conditionality. Wunder \& Sheil are incorrect to assert that the scheme we propose is a tax: taxes are normally understood to be compulsory fees levied by a government. Government and compulsion are absent in our proposed scheme.

In our view the key difficulty of applying PES logics to the wildlife media lies in the fact that film-makers and broadcasters are co-producers of the ecosystem services they use. For instance, the tiger and great white shark provide a variety of cultural services not because of what they intrinsically are but because they have characteristics that afford types of media representations that interact with wider cultural frames. This blurs the distinction between user and producer and makes a contractual transfer between the two parties problematic. Barnes et al. (2008) propose that the common asset trust, an established and widely used legal mechanism to protect and manage assets for specific beneficiaries, could be extended to the management of common pool resources. In the case of wildlife broadcasters such a trust would provide a vehicle for them to generate and pool funds to pay for the conservation and restoration of the nature-based ecosystem services that underpin their business.

We share Wunder \& Sheil's concern that some conservation financing models are short-sighted because they risk undermining forms of engagement with nature that promote pro-conservation constituencies. We subscribe to an early 2oth century value of the conservation movement: 'Free enjoyment of the noblest works of nature is one of man's most precious privileges, not to be abridged by private right for greed or gain' (Ladle et al., 2011). Sadly, it appears that delivery of the common pool resource of 'affordable enjoyment of nature' is increasingly beyond the financial resources of governments and conservation groups. These two sectors co-produce, use and pay for the maintenance of cultural ecosystem services. As the third and prominent co-producer and user of cultural ecosystem services it seems reasonable to ask that wildlife broadcasters likewise assume responsibility for the 'payment' dimension of this relationship.

Wunder \& Sheil argue that wildlife films have been instrumental in promoting pro-conservation sentiments and attitudes. We agree. The early films of Martin \& Osa Johnson (1917-1937), the undersea films of Jacques Cousteau (1956-1980) and the Oscar-winning 'Serengeti shall not die' 
TABLE 1 Twelve testable claims on the relative contribution of the wildlife film industry to conservation (developed from Palmer, 2010; Phuntsho, 2010; Bouse, 2011; Wunder \& Sheil, 2013).

1 Exposure to nature via wildlife films builds public support for conservation.

2 Broadcasting wildlife films counteracts a loss of biophilia among the public.

3 Television coverage of iconic species \& places represents free advertising for ecotourism that contributes to the income of parks.

4 Wildlife films create a positive externality that drives private donations to conservation NGOs.

5 If the wildlife media had to pay something for conservation it would reduce the amount of nature broadcasting on TV.

6 Wildlife broadcasting promotes a false sense that all is well in the natural world.

7 The constant repetition of images of wondrous, active, abundant \& close-up nature means that real/actual engagements with nature are an anticlimax.

8 The wildlife media exploit the knowledge, goodwill \& capacities of conservation practitioners working in developing countries.

9 The profits accrued to the broadcasting companies are incommensurate with the income received by parks where film footage is captured.

10 The wildlife media play to populist attitudes (e.g. white scientific supremacy) that are outmoded \& out of sync with both the practice of conservation \& the contemporary policy \& political norms within which conservation acts.

11 Media corporations create celebrity presenters whom they use to talk about conservation in preference to leading conservation practitioners.

12 The wildlife media have been \& may still be subjected to practices that are dubious from animal welfare \& certain ethical standpoints.

by Bernhard \& Michael Grzimeks (1957) are among the many examples of films promoting conservation agendas. However, the past is not a reliable guide to the future. It is important to recognize that wildlife films are not nature or even direct representations of nature: they are media products. The styles, norms and narratives of wildlife film productions are shaped by commercial imperatives in entertainment markets. We think it is generally acknowledged that the conservation advocacy content of wildlife films has declined.

Asserting that wildlife films make a significant contribution to conservation is not the same as proving that they do. As we argued (Jepson et al., 2011) there is little academic work examining the interplay between contemporary wildlife films and conservation: the topic is absent from the recently published Oxford Handbook of Environmental and Conservation Psychology (Clayton, 2012) and there is only one substantive examination of wildlife films from a media studies perspective (Bouse, 2011). Wunder \& Sheil present a number of arguments that may be valid but that lack a proper evidence base. Anecdotal and case study evidence could similarly be presented to suggest that wildlife broadcasters exploit and misrepresent conservationists.

In an effort to move beyond assertion we have summarized the claims of Wunder \& Sheil, and others, in a set of 12 testable claims (Table 1 ). We suggest that research that tests these, or similar claims, will create a stronger evidencebase to inform debates on the extent to which the wildlife film industry supports conservation and whether its current financial contributions to the cause are appropriate.

To sum up, the wildlife film industry is a major component of international popular culture yet as a media genre it has been subjected to very little academic and public critique. Examining the feasibility of applying PES logics to this sector exposes both the difficulties of monetizing cultural ecosystem services and extending payments to users who deliver a popular and cherished service. Our proposed scheme captures the principle that the ecosystem services should shape the design of the payment scheme. The goal is to widen and increase financial flows for the protection and restoration of ecosystems, and a varied and innovative portfolio of payment schemes will deliver this aim better. We remain of the view that with deliberation and support our proposal could be developed into a workable scheme that would realign conservation, the media and the viewing public, and bring benefits to all.

\section{References}

Barnes, P., Costanza, R., Hawken, P., Orr, D., Ostrom, E., Umaña, A. \& Young, O. (2008) Creating an earth atmospheric trust. Science, 319, 724-724.

Bouse, D. (2011) Wildlife films. University of Pennsylvania Press, Philadelphia, USA.

Clayton, S. (ed.) (2012) The Oxford Handbook of Environmental and Conservation Psychology, Oxford University Press, Oxford, UK.

Farley, J. \& Costanza, R. (2010) Payments for ecosystem services: from local to global. Ecological Economics, 69, 2060-2068.

Gómez-Baggethun, E., De Groot, R., Lomas, P.L. \& Montes, C. (2010) The history of ecosystem services in economic theory and practice: from early notions to markets and payment schemes. Ecological Economics, 69, 1209-1218.

Jepson, P., Jennings, S., Jones, K.E. \& Hodgetts, T. (2011) Entertainment value: should the media pay for nature conservation? Science, 334, 1351-1352.

Ladle, R.J., Jepson, P. \& Gillison, L. (2011) Social values and conservation biogeography. In Conservation Biogeography (eds R. Ladle \& R.J. Whittaker), pp. 13-30. Oxford University Press, Oxford, UK.

Palmer, C. (2010) Shooting in the Wild. Sierra Club Books, San Francisco, USA.

Phuntsho, K. (2010) Stealing our thunder. Kuensel Online. Http://www.kuenselonline.com [accessed 5 October 2010].

Westman, W.E. (1977) How much are natures services worth? Science, 197, 960-964.

Wunder, S. \& Sheil, D. (2013) On taxing wildlife films and exposure to nature. Oryx, $47,483-485$. 